\title{
A Large-Scale Identification of Sediment-Associated Risks of Contamination with Heavy Metals and Organics: Indicators and Algorithms
}

\author{
Yovana Todorova*, Ivaylo Yotinov, Stilyana Lincheva, Yana Topalova \\ Department of General and Applied Hydrobiology, Faculty of Biology, Sofia University "St. Kliment Ohridski", \\ Sofia, Bulgaria \\ Email: yovana.todorova@gmail.com
}

Received 7 January 2015; accepted 27 January 2015; published 30 January 2015

Copyright (C) 2015 by authors and Scientific Research Publishing Inc.

This work is licensed under the Creative Commons Attribution International License (CC BY). http://creativecommons.org/licenses/by/4.0/

(c) (i) Open Access

\section{Abstract}

As mediators in key biotransformation processes, the complex enzyme activities (measured as a total of extracellular and intracellular activity on sub-organism, organism and supra-organism level) have a high potential to be used as reliable indicators for risk identification in co-contaminated sediments with organics and heavy metals. Two enzyme activities-dehydrogenase activity (TTC-DHA) and phosphatase activity index (PAI) were measured by use of methods with tetrazolium chloride and p-nitrophenyl phosphate in polluted sediments of Middle Iskar River part, Bulgaria. The environmental state of river sector has been strongly influenced by the organics, nutrients, xenobiotics pollutants and by the intensive hydrotechnical activity for construction of 9 micro-hydro power plants. The change of hydrological regime was a factor for intensive sediment accumulation and concentration of pollutants in the area of the cascade. Data for total activities of dehydrogenases and phosphatases in sediments were compared with total count of culturable sediment bacteria and pollutants concentrations. The results showed that the enzyme activities correlated positively with bacterial abundance in sediments and organics content in sediments and negatively with concentrations of xenobiotic pollutants (heavy metals). This approves a high potential of enzyme indicators for regulation of ecosystem self-purification capacity and for early assessment of sediment-associated risks of co-contamination. The correlative relations allow dividing the mathematical algorithms for control and management of processes in technologically influenced hydroecosystem.

\section{Keywords}

Risk Identification, Dehydrogenase Activity, Phosphatase Activity Index, Sediments,

\footnotetext{
${ }^{*}$ Corresponding author.
}

How to cite this paper: Todorova, Y., Yotinov, I., Lincheva, S. and Topalova, Y. (2015) A Large-Scale Identification of Sediment-Associated Risks of Contamination with Heavy Metals and Organics: Indicators and Algorithms. Journal of Water Resource and Protection, 7, 101-110. http://dx.doi.org/10.4236/jwarp.2015.72008 


\section{Co-Contamination}

\section{Introduction}

Pollution of sediments with organic and toxic contaminants has received increased attention for its widespread and difficult technological processing for pollutants removal. Contaminated sediments act as an important sink of pollutants, as well as a potential non-point pollution source which may directly affect overlying waters and have a critical impact for ecosystem and human health [1] [2]. These concerns continue to drive the need for early identification of sediment-associated risks, development of specific remedial technologies for solving of this acute environmental problem and define the effective management of contaminated sediments as a key point of the global pollution control [3] [4].

A typical example in Bulgaria is the middle part of the Iskar River, where this problem remains very urgent and the river sector continues to be one of the critical sites with a high risk level for the environment and humans. The ecological state of river sector has been strongly influenced by the organics, nutrients and xenobiotics pollutants. The river bed sediments are historical contaminated with difficult biodegradable hazardous pollutants. To date, the intensive hydrotechnical activity for construction of 9 micro-hydro power plants (cascade Middle Iskar) is in progress. The change of hydrological regime is a factor for intensive sediment concentration in area and uncontrollable deaccumulation/accumulation of pollutants. These heterogeneous impacts influence the all processes of river metabolism and biotic communities; deteriorate significantly the water quality and sediment status [5]-[7]. The identification of primary risks and adequate management of sediment pollution with removal of accumulated contaminants is necessary for the improvement of ecosystem health and sustainable functioning of energy facilities in Middle Iskar River [8] [9].

Biological treatment (bioremediation) of polluted environmental sites is one of the most promising methods for removal of wide range of contaminants in sediments. The bioremediation is cost effective and environmentally sound biotechnology since this type of contamination treatment stimulates natural processes and can result in the complete destruction of hazardous compounds into non-toxic products [10]-[12]. But for target bioremediation application with high efficiency, the development and verification of indicators and algorithms for identification of areas and substances of concern in relation to the self-purification capacity of ecosystem is necessary.

As mediators in key biotransformation processes of pollutants, the enzyme activities have a high potential to be used as reliable indicators for assessment of self-purification potential and sediment-associated risks of contamination with various range of substances. The complex enzyme activities measured as a total of extracellular and intracellular activity on sub-, organism and supra-organism level describe the functionality of biological system and give the information for the mechanisms and rate of biotransformation processes on ecosystem level [7] [13]. Dehydrogenase and phosphatase activities are considered to exist in aquatic systems, soils and sediments as integral parts of complex enzyme profile and give information about effect of environmental conditions (including nutrients, organics, pollutants concentration and type) on microbial activities [14]-[19].

The aim of this study is to evaluate the potential of total dehydrogenase and phosphatase activities as indicators for early identification of risks, associated with sediment contamination in technologically managed ecosystem.

\section{Materials and Methods}

\subsection{Study Area}

The study was carried out in the area of Middle Iskar cascade-33 km river sector between villages Svoge and Elisejna in middle part of the Iskar River, Bulgaria. The Iskar River is situated in the Western part of Bulgaria and entirely flows through the territory of the country. Iskar is the longest Bulgarian river (368 km) with 8650 $\mathrm{km}^{2}$ basin area and mean annual runoff of $37.57 \mathrm{~m}^{3} / \mathrm{s}$ in the study sector. In its middle part the river is long-term receptor of urban and industrial sewage of Sofia area (capital of Bulgaria) and this pollution results in serious contamination of waters and sediments. The construction of Middle Iskar Cascade of 9 micro-hydro power plants with barrages and power stations has been started since 2000s. Flow regulation combined with other anthropogenic impacts deepen the environmental and technological problems in management of ecosystem. 


\subsection{Sampling and Experimental Strategy}

The location of sampling sites (Figure 1) was selected on the base of implementation of long-term extensive monitoring program for assessment of water and sediment quality in connection with construction and functioning of hydropower plants in this area [5] [7]-[9] [20]. The first site was at the beginning of the river sectorProkopanik (Prok.) and gave information for pollution from Sofia area and initial ecosystem potential for adequate response; the second and third sites Lakatnik and Svrazhen (Lak. and Svr.) were located in the cascade and gave information for the fate of pollutants and ecosystem response in technologically managed conditions; the last sampling site was at the end of river sector Gabrovnica (Gabr.) and allowed the application of final process control. The all sampling sites were located in "river" sectors before or after the impoundments of cascade for elimination of strong effect from technological operation of power stations and regular release of accumulated sediments at dams.

The analyses of three groups of indicators were included in experimental design:

1) Water quality parameters for complete assessment of pollution in the sampling sites and concentrations of organics and xenobiotic pollutants (heavy metals) analyzed in their preferred for accumulation matrix-sediments;

2) Total microbial count in sediments as the most frequently used monitoring parameter for the structural and functional state of microbial community;

3) Key enzymological parameters (Dehydrogenase activity and Index of Phosphatase activity measured as total activities)-indicators for functioning of the microbial community and the realization of main transformation processes.

The samples (a total of 24) from waters and sediments were collected during the high (spring) and low (summer) flow period of three years 2011-2013. The sediment samples were obtained by manual dredging from 1 $15 \mathrm{~cm}$ depth. The stones and plant fragments were removed by passing the samples through a $2 \mathrm{~mm}$ sieve. Each collected sample consisted of at least $1 \mathrm{~kg}$ of sediment and was contained in a separate sealed plastic bag, placed in a cooler at $4^{\circ} \mathrm{C}$, and transported to the laboratory immediately for further analysis. The in situ analyses of physicochemical parameters were carried out and samples from waters were collected also for more complete description of environmental state of river sector.

\subsection{Analytical Procedures}

The physicochemical parameters (oxygen concentration and $\mathrm{pH}$ ) of waters were measured in situ with portable Oxy-meter Handylab Ox1/set and pH-meters Handylab pH11/set (WTW). After transferring to the laboratory, the samples were analyzed in triplicate for determination of organic loading as COD (Chemical Oxygen

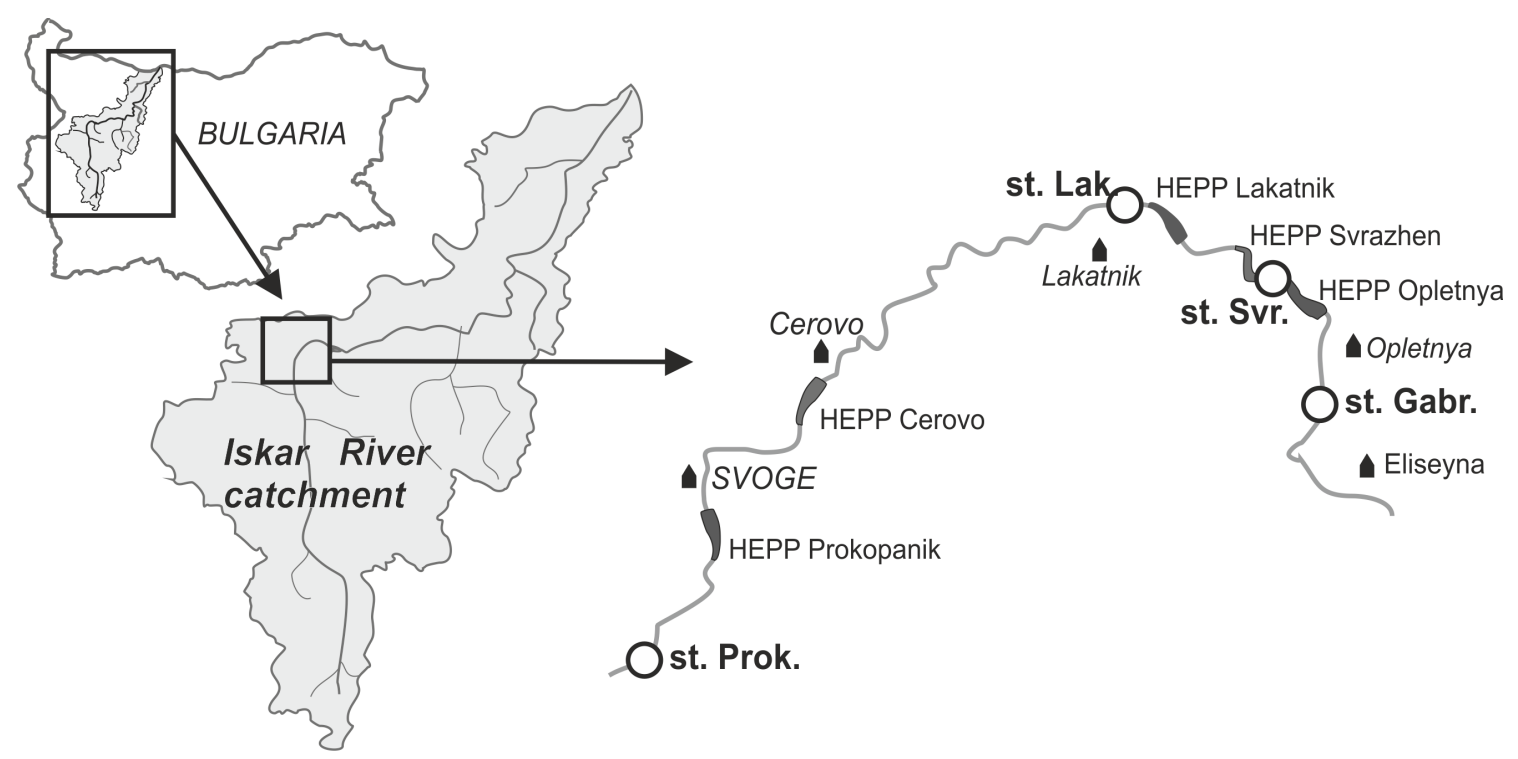

Figure 1. Iskar River catchment and location of sampling sites in area of Middle Iskar Cascade. 
Demand-dichromatic EPA 410.4/ISO 6060 method) [21]. The ammonium, nitrite, nitrate and phosphate concentrations were measured after filtering of samples (main pore size $0.45 \mu \mathrm{m}$ ) and determination by colorimetric methods according to the BNS-EN-ISO. TOC (total organic carbon) analyses of sediment samples (years 2011 and 2012) were performed on TOC-V analyzer SSM-5000A, Shimadzu Corporation by combustion catalytic oxidation method. For analyses of heavy metals content the sediment samples from Prok. and Gabr. sampling sites were air dried, then powdered and finally passed through a $500 \mu \mathrm{m}$ sieve. The heavy metals concentrations were determined by atomic absorption spectrophotometry for $\mathrm{As}, \mathrm{Cd}, \mathrm{Cu}, \mathrm{Pb}$ and $\mathrm{Zn}$ and by cold vapour atomic absorption spectrometry for $\mathrm{Hg}$. The concentrations were presented in $\mathrm{mg} / \mathrm{kg}$.

The Total Microbial Count (CFU/g) was determined by use of count-plate technique on Nutrient agar for 24 $48 \mathrm{~h}$ at $35^{\circ} \mathrm{C}$.

For determination of enzyme activities the sediment samples were sonicated (UD-20 automatic) $3 \times 10 \mathrm{~s}$. Dehydrogenase activity (TTC-DHA) was measured according to the method of Lenhard et al. [22] by the reduction of 2, 3, 5-triphenyl tetrazolium chloride (TTC). Phosphatase activity index (PAI) was determined as an average value of activities of acid, neutral and alkaline phosphatases. The method was based on transformation of p-nitrophenolphosphate [19].

The enzyme activities were presented per mg of total sediment protein. The protein content was determined according to micro-biuret method [23].

The data were means of three or more repeats with presented standard deviations.

\section{Results and Discussion}

\subsection{Water Quality in River Sector-Actual State}

From all sampling sites, the samples from water phase were collected for analyses of basic chemical quality parameters (Table 1). The obtained results were compared with the criteria for achievement of good ecological state of surface waters in terms of low levels of chemical pollution and healthy ecosystem according to Water Framework Directive (WFD) [24]. The concentration of $\mathrm{N}^{-\mathrm{NH}_{4}}$ ranged from 0.156 to $4.184 \mathrm{mg} / \mathrm{L} ; \mathrm{N}-\mathrm{NO}_{2}$ from 0.026 to $0.302 \mathrm{mg} / \mathrm{L} ; \mathrm{N}-\mathrm{NO}_{3}$ from 0.922 to $4.958 \mathrm{mg} / \mathrm{L} ; \mathrm{P}^{-P} \mathrm{H}_{4}$ from 0.213 to $0.967 \mathrm{mg} / \mathrm{L}$; COD from 3212 to $20,932 \mathrm{mgO}_{2} / \mathrm{L}$ with high temporal and spatial variations. During the 3-year period of study, the ecosystem achieved the criteria for good state only by the parameters "dissolved oxygen" and " $\mathrm{pH}$ ". Other parameters (especially N-NH $4, \mathrm{~N}_{4} \mathrm{NO}_{2}$ and $\mathrm{P}-\mathrm{PO}_{4}$ ) showed a trend for permanent deterioration of water quality. The dynamics of nitrates had a clearly presented seasonal pattern with higher concentrations during the summer low flow. The reduced form of nitrogen (ammonium) usually was in high concentrations at the beginning of the river sector, while the nitrites and nitrates increased their content at the end sampling site. This spatial dynamics indicated not only the high nitrogen loading of system but also the fast oxidation transformation processes of nitrogen in the area of the cascade.

The spatio-temporal trends of hydrochemical parameters showed the significant anthropogenic disturbance, high environmental stress and presence of serious loading with nutrients and organics in study ecosystem. But the high available content of nitrogen, phosphorus and easy biodegradable organics can also be stimulating factor for the in situ microbial community and therefore enhance the future bioremediation [10] [12] [25].

\subsection{Organic Content and Pollution Status of Sediments}

Total Organic Carbon (TOC) is a measure of the concentration of organic matter in sediments. It represents the long-term, average burial rate of organic material in the sediments. The presence of organic matter in sediment is directly related to the bioavailability of the heavy metals - the metals bound to biogenic carbonates and organic matter are much more available [26] [27]. The unified criteria for TOC in freshwater sediments are not still established on European or national level but the other recommendations determine the values under $1 \%$ as low and the values above $3 \%$ as indicator of strong anthropogenic impact [28].

The content of TOC in studied sediments varied in range: $0.09 \%-0.56 \%$ (Figure 2). The lower values were detected in 2011 and at the first sampling site Prok. The measured values of TOC $<1 \%$ could be indicator for fast mineralization of organics in the system without retention in sediments but this low content could be potential obstacle for applicability of some bioremediation technologies and for achieving the aims of integrated river basin management, too. 
Table 1. Water quality basic chemical parameters in study river sector for high (spring) and low flow (summer) periods of 2011, 2012 and 2013. The data marked with grey colour do not achieve the criteria for good ecological state.

\begin{tabular}{|c|c|c|c|c|c|c|c|c|}
\hline & \multicolumn{4}{|c|}{ 2011-high flow period } & \multicolumn{4}{|c|}{ 2011-low flow period } \\
\hline & Prok. & Lak. & Svr. & Gabr. & Prok. & Lak. & Svr. & Gabr. \\
\hline Dissolved $\mathrm{O}_{2}, \mathrm{mg} / \mathrm{L}$ & 7.62 & 9.05 & 8.22 & 9.30 & 6.00 & 8.12 & 6.35 & 8.00 \\
\hline $\mathrm{pH}$ & 7.42 & 7.92 & 7.77 & 7.86 & 7.64 & 8.00 & 7.88 & 7.96 \\
\hline $\mathrm{COD}, \mathrm{mgO}_{2} / \mathrm{L}$ & 9.788 & 10.610 & 3.212 & 8.692 & 18.009 & 5.678 & 3.760 & 11.158 \\
\hline $\mathrm{N}-\mathrm{NH}_{4}, \mathrm{mg} / \mathrm{L}$ & 0.250 & 0.331 & 0.488 & 0.474 & 2.100 & 0.258 & 0.234 & 0.156 \\
\hline $\mathrm{N}-\mathrm{NO}_{2}, \mathrm{mg} / \mathrm{L}$ & 0.149 & 0.233 & 0.191 & 0.186 & 0.191 & 0.050 & 0.026 & 0.026 \\
\hline $\mathrm{N}-\mathrm{NO}_{3}, \mathrm{mg} / \mathrm{L}$ & 1.311 & 2.793 & 2.724 & 2.807 & 3.167 & 3.456 & 3.488 & 3.831 \\
\hline \multirow[t]{3}{*}{$\mathrm{P}-\mathrm{PO}_{4}, \mathrm{mg} / \mathrm{L}$} & 0.388 & 0.296 & 0.332 & 0.326 & 0.691 & 0.967 & 0.512 & 0.496 \\
\hline & \multicolumn{4}{|c|}{ 2012-high flow period } & \multicolumn{4}{|c|}{ 2012-low flow period } \\
\hline & Prok. & Lak. & Svr. & Gabr. & Prok. & Lak. & Svr. & Gabr. \\
\hline Dissolved $\mathrm{O}_{2}, \mathrm{mg} / \mathrm{L}$ & 6.99 & 9.68 & 7.57 & 9.36 & 5.98 & 8.80 & 8.76 & 8.37 \\
\hline $\mathrm{pH}$ & 7.49 & 8.30 & 7.85 & 8.18 & 7.41 & 8.10 & 7.90 & 7.84 \\
\hline $\mathrm{COD}, \mathrm{mgO}_{2} / \mathrm{L}$ & 3.351 & 11.223 & 6.240 & 8.821 & 13.351 & 7.870 & 9.240 & 9.788 \\
\hline $\mathrm{N}-\mathrm{NH}_{4}, \mathrm{mg} / \mathrm{L}$ & 1.300 & 0.523 & 0.397 & 0.234 & 2.832 & 0.843 & 2.002 & 2.133 \\
\hline $\mathrm{N}-\mathrm{NO}_{2}, \mathrm{mg} / \mathrm{L}$ & 0.211 & 0.225 & 0.167 & 0.096 & 0.121 & 0.060 & 0.046 & 0.039 \\
\hline $\mathrm{N}-\mathrm{NO}_{3}, \mathrm{mg} / \mathrm{L}$ & 1.355 & 1.941 & 2.030 & 2.183 & 2.607 & 2.756 & 1.922 & 1.788 \\
\hline \multirow[t]{3}{*}{$\mathrm{P}-\mathrm{PO}_{4}, \mathrm{mg} / \mathrm{L}$} & 0.229 & 0.242 & 0.255 & 0.257 & 0.291 & 0.280 & 0.216 & 0.213 \\
\hline & \multicolumn{4}{|c|}{ 2013-high flow period } & \multicolumn{4}{|c|}{ 2013-low flow period } \\
\hline & Prok. & Lak. & Svr. & Gabr. & Prok. & Lak. & Svr. & Gabr. \\
\hline Dissolved $\mathrm{O}_{2} . \mathrm{mg} / \mathrm{L}$ & 7.45 & 9.50 & 8.40 & 9.34 & 7.50 & 9.93 & nd & 9.94 \\
\hline $\mathrm{pH}$ & 7.45 & 7.68 & 7.68 & 7.61 & 7.72 & 7.97 & nd & 8.01 \\
\hline COD. $\mathrm{mgO}_{2} / \mathrm{L}$ & 6.500 & 10.062 & 20.932 & 14.721 & 10.020 & 10.555 & nd & 10.488 \\
\hline $\mathrm{N}-\mathrm{NH}_{4} \cdot \mathrm{mg} / \mathrm{L}$ & 1.143 & 0.461 & 0.373 & 0.362 & 4.184 & 1.363 & nd & 0.796 \\
\hline $\mathrm{N}-\mathrm{NO}_{2} \cdot \mathrm{mg} / \mathrm{L}$ & 0.082 & 0.132 & 0.134 & 0.147 & 0.173 & 0.302 & nd & 0.298 \\
\hline $\mathrm{N}-\mathrm{NO}_{3} . \mathrm{mg} / \mathrm{L}$ & 0.922 & 2.195 & 2.807 & 3.080 & 2.737 & 4.538 & nd & 4.958 \\
\hline $\mathrm{P}-\mathrm{PO}_{4} \cdot \mathrm{mg} / \mathrm{L}$ & 0.347 & 0.371 & 0.393 & 0.401 & 0.232 & 0.231 & nd & 0.213 \\
\hline
\end{tabular}

The pollution status of river sediments in Middle Iskar Cascade was assessing by the concentrations of 6 heavy metals_-As, Cd, Cu, Hg, Pb and Zn (Table 2). The range of metals content was: 6 - $23.3 \mathrm{mg} / \mathrm{kg}$ for As; 0.2 - $1 \mathrm{mg} / \mathrm{kg}$ for Cd; 36 - 82.5 for Cu; 0.05 - $1.9 \mathrm{mg} / \mathrm{kg}$ for Hg; 27 - $53 \mathrm{mg} / \mathrm{kg}$ for Pb and 158 - $305 \mathrm{mg} / \mathrm{kg}$ for $\mathrm{Zn}$. The measured concentrations had wide variations but the content of arsenic and mercury was close or higher than the maximum admissible levels in 2011 and 2013 at Gabr. for As, in 2011 at two sampling sites for Hg. These high concentrations of toxic, non-biodegradable substances can affect negatively the abundance, structural and functional diversity of sediment microbial community [29]-[31]. 


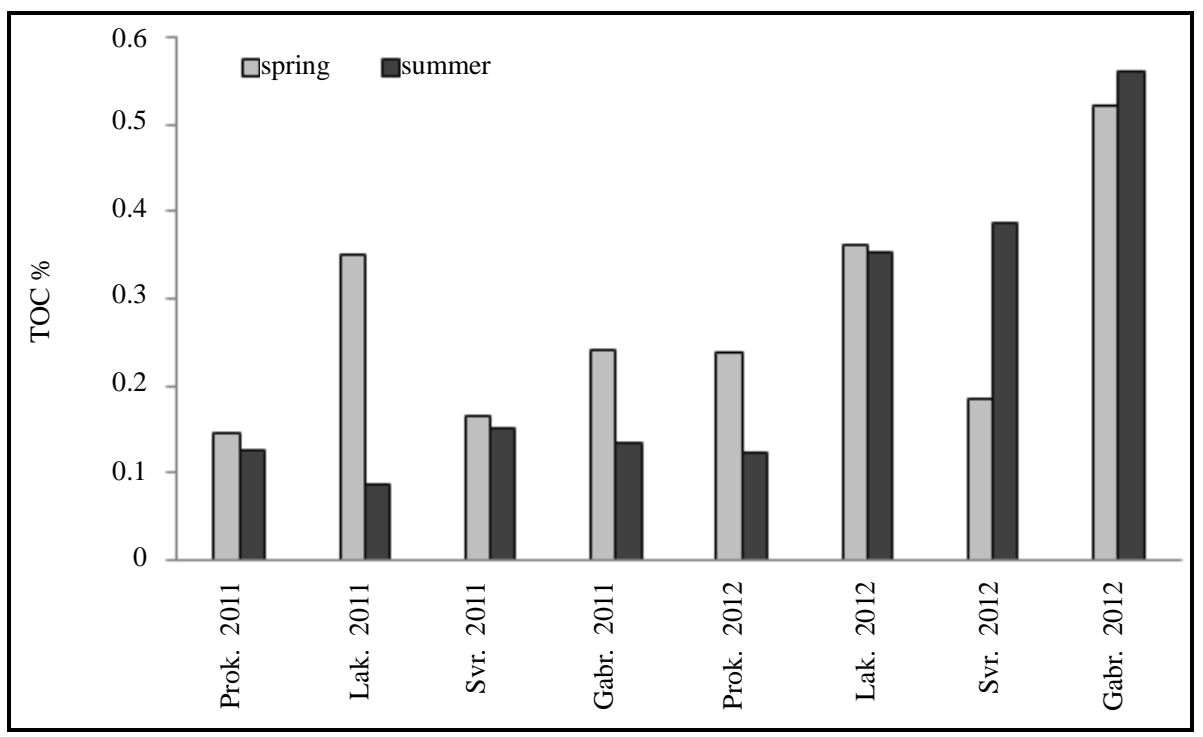

Figure 2. Total organic carbon (TOC) in sediments of Middle Iskar cascade in 2011 and 2012.

Table 2. Concentrations of heavy metals (mg/kg) in sediments of Middle Iskar Cascade. The data marked with grey colour are close or higher than maximum admissible concentrations.

\begin{tabular}{ccccccc}
\hline Prok. & As & $\mathrm{Cd}$ & $\mathrm{Cu}$ & $\mathrm{Hg}$ & $\mathrm{Pb}$ & $\mathrm{Zn}$ \\
\hline 2011 & 12.5 & 0.8 & 36 & $\mathbf{1 . 2}$ & 41 & 185 \\
2012 & 11 & 1 & 58 & 0.2 & 53 & 246 \\
2013 & 12 & 0.2 & 39 & 0.05 & 27 & 169 \\
Gabr. & & & & & & \\
\hline 2011 & $\mathbf{2 3 . 3}$ & 0.54 & 82.5 & $\mathbf{1 . 9}$ & 53 & 158 \\
2012 & 6 & 1 & 74 & 0.2 & 52 & 305 \\
2013 & $\mathbf{2 3}$ & 1 & 64 & 0.05 & 38 & 178 \\
\hline
\end{tabular}

\subsection{Sediment Microbial Community-Culturable Bacteria Screening}

The in situ microbial community (culturable bacteria) in sediments of Middle Iskar Cascade was presented in high numbers-from 0.3 to $3.1 \times 10^{6} \mathrm{CFU} / \mathrm{g}$ (Figure 3). The higher microbial count was determined at the beginning of the cascade (Prok.) in 2011 and in Lak. and Svr. during the 2013. The seasonal dynamics of this microbial indicator did not show the clear trend-only in 2012 the values from summer sampling were higher than these from spring sampling. The decrease of CFU was observed at the last sampling site-Gabr. where the lowest number was determinate in $2011-0.3 \times 10^{6} \mathrm{CFU} / \mathrm{g}$. This low value was in correspondence with the low content of TOC (Figure 2) and high heavy metals concentrations in this period (Table 2).

\subsection{PAI and TTC-DHA in Sediments}

Phosphatases catalyzes the hydrolysis of phosphate esters, releasing phosphate groups bound in more complex substrates such as organic matter, thus is responsible for the mineralization of organic phosphorus in the form of inorganic phosphorus which is available for the requirements of microorganisms and macrophytes [32].

The mean values of phosphatase activity index (PAI) were in range of $0.153-0.997 \mathrm{mkM} \mathrm{pNP} / \mathrm{min} \mathrm{mg} \operatorname{Pr}$ (Figure 4). The minimal values were measured at Lak. and Gabr. during the summer low flow period in 2011; at Svr. during the spring high flow period in 2012. In these sampling sites the TOC concentrations in sediments 


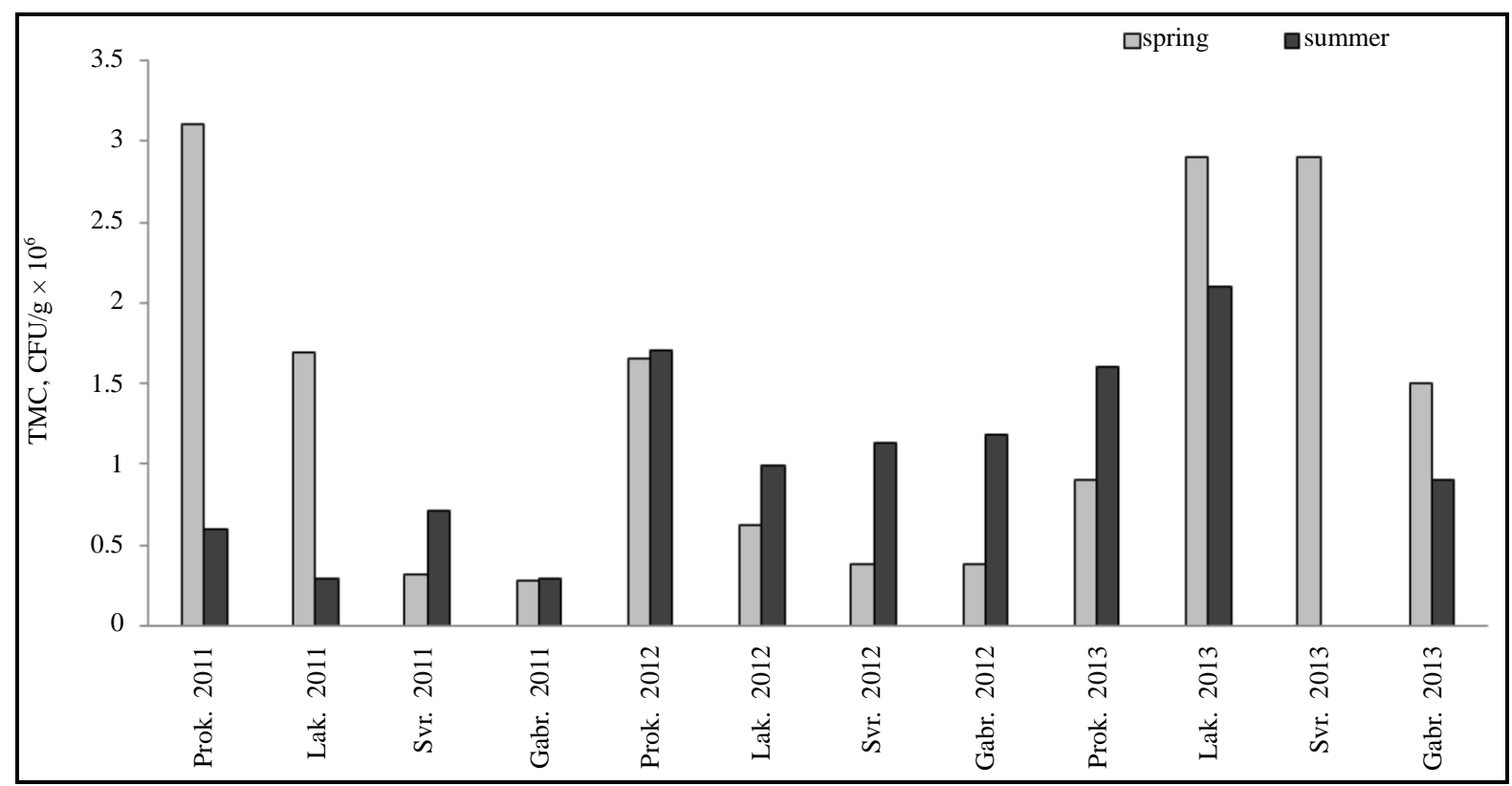

Figure 3. Total count of culturable bacteria (CFU/g) in sediments during the 2011-2013: spatio-temporal dynamics.

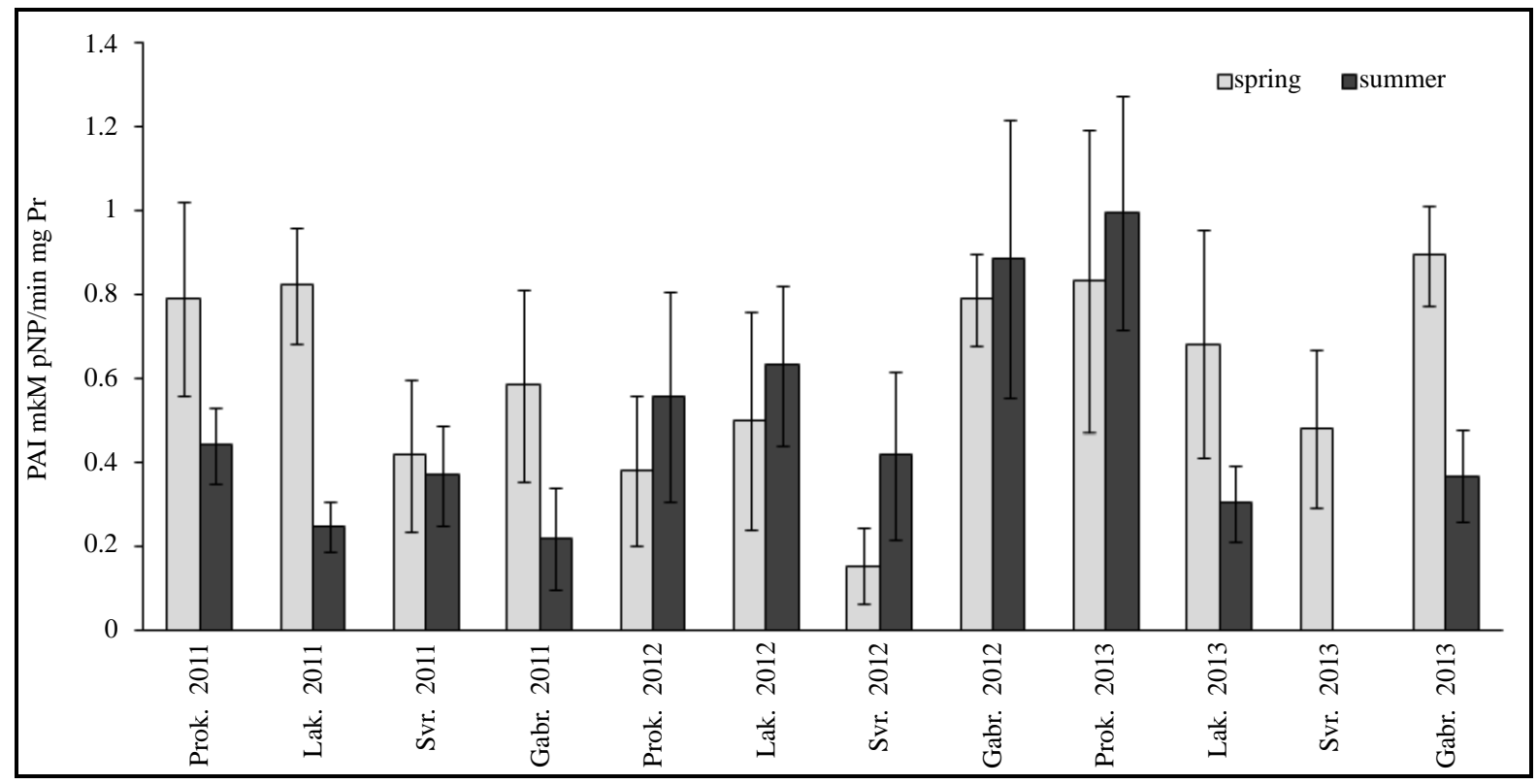

Figure 4. PAI in sediments during the 2011-2013: spatio-temporal dynamics.

decreased significantly (Figure 2) and this low content affected negatively the abundance and functional state of microbial community and PAI. In summer of 2011 the inhibition effect of heavy metal pollution was also presented on functional level and the low PAI could be result of cumulative impacts in the system.

Dehydrogenase activity reflects the work of a group of intracellular enzymes that are present in the microbiota, realize the metabolic reactions involved in oxidative energy transfer and are considered a good indicator of microbial activity [32].

Data for TTC-DHA in sediments of Middle Iskar cascade were presented on Figure 5. The dynamics of enzyme activity had a clear seasonal pattern-the higher values from 6.36 to $33.51 \mathrm{mkM} \mathrm{H}+/ \mathrm{min} \mathrm{mg} \operatorname{Pr} \times 10^{-6}$ were determinate during the spring high flow period. In the summer values were in the range of 5.81 - 22.28 $\mathrm{mkM} \mathrm{H}+/ \mathrm{min} \mathrm{mg} \operatorname{Pr} \times 10^{-6}$. The increase in the total activity of dehydrogenases was observed in the sediments 
of sampling sites inside the cascade—Lak. and Svr. The same relation with the TOC as PAI was presented too.

\subsection{Correlation between Enzyme Activities and Other Indicators}

Phosphatases are important for realization of $\mathrm{P}$ cycling in aquatic environment, involving in mineralization of organic P and releasing phosphates for macrophytes. Dehydrogenases play an important role in the oxidation of organic matters. This functional role determines the direct relationships of two enzyme activities with the concentration and fate of organics in the system. The analysis of correlation matrix between parameters (Table 3) confirmed the positive correlation between PAI and TOC, TTC-DHA and TOC $(r=0.785$ and 0.702 respectively) despite the low values of TOC in sediments of Middle Iskar cascade. The significant correlation with COD values of waters was not detected. PAI and TTC-DHA correlated significantly with the total microbial count in sediments-indicator for capabilities of in situ microbial community. But the co-contamination of river sector with heavy metals had a negative effect on enzyme activities - the values of PAI was correlated strongly negatively with the concentrations of arsenic and mercury $(r=-0.777$ and -0.663$)$; TTC-DHA was not presented a significant correlation with heavy metals content.

The data for in situ PAI confirmed the previous data for inhibition effect of other heavy metals $\mathrm{Cd}, \mathrm{Cu}, \mathrm{Pb}$ and $\mathrm{Zn}$ measured in sediments of Middle Iskar cascade in model laboratory system [7] [8] and for other soil and aquatic ecosystems [29]-[31] [33]. The response of TTC-DHA to metal contamination in studied sediments was not unidirectional both in lab and in situ cownditions [7] [8].

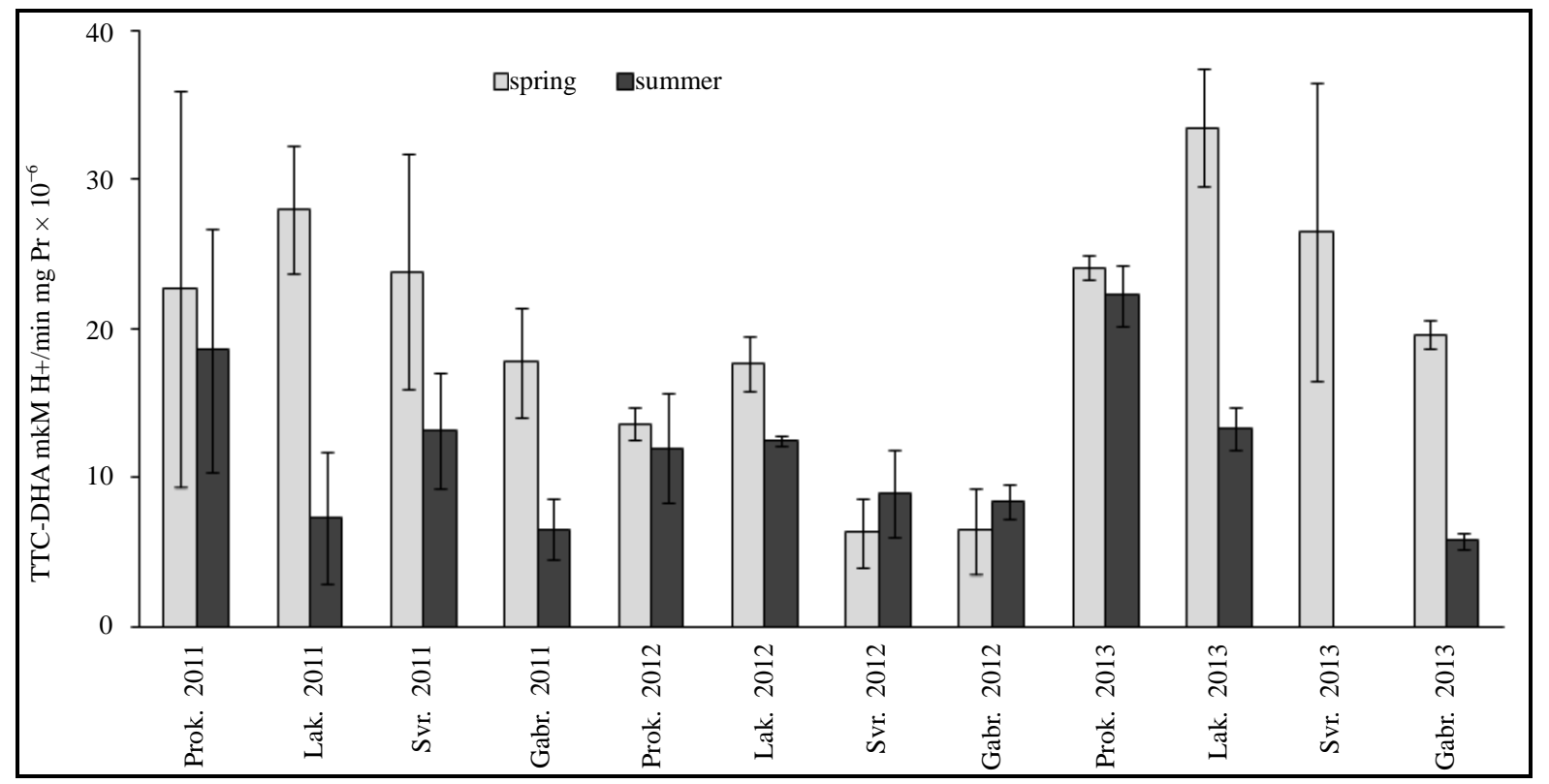

Figure 5. TTC-DHA in sediments during the 2011-2013: spatio-temporal dynamics.

Table 3. Pearson correlation matrix between parameters (values in grey colour are different from 0 with a significance level $=0.05$ ).

\begin{tabular}{|c|c|c|c|c|c|c|c|}
\hline & PAI & TTC-DHA & TOC & CODw & TMC & As & $\mathrm{Hg}$ \\
\hline PAI & 1 & & & & & & \\
\hline TTC-DHA & 0.535 & 1 & & & & & \\
\hline TOC & 0.785 & 0.702 & 1 & & & & \\
\hline CODw & 0.430 & 0.080 & 0.376 & 1 & & & \\
\hline TMC & 0.601 & 0.622 & 0.673 & 0.121 & 1 & & \\
\hline As & -0.777 & -0.461 & - & - & -0.060 & 1 & \\
\hline $\mathrm{Hg}$ & -0.663 & -0.149 & - & - & -0.837 & 0.435 & 1 \\
\hline
\end{tabular}




\section{Conclusions}

The data confirmed the presence of complex pollution (co-contamination with nutrients, organics and heavy metals) in Middle Iskar River ecosystem with multidirectional effect. The substances of concern in risk identification are nitrogen and phosphorus in waters, and heavy metals in sediments (Hg and As). The studied enzyme activities-TTC-Dehydrogenase and Phosphatase Activity Index correlated positively with abundance of culturable sediment bacteria and concentration of organics in sediments. The high concentrations of heavy metals affected negatively the structural parameter (total microbial count) and the functional indicators for its metabolitic activity - the microbial count and enzyme activities reduced their values twice. This approves a high potential of enzyme indicators for regulation of ecosystem self-purification capacity and for early assessment of bioremediation technologies effectiveness for removal of the sediment contaminants.

The adequate contaminant monitoring and remediation program should be implemented in area of Middle Iskar cascade for minimization of the impacts. The correlative relations between parameters allow dividing the algorithms for effective control and management of processes in this technologically influenced hydroecosystem.

\section{Acknowledgements}

This work was supported by the Sofia University Research Fund under Grant 142/08.05.2014 and National Science Fund, Bulgaria under Grant DMU 03-56 (2011-2015).

\section{References}

[1] Santos, B.J.C., Beltran, R. and Gomez, A.J.L. (2003) Spatial Variations of Heavy Metals Contamination in Sediments from Odiel River (Southwest Spain). Environment International, 29, 69-77. http://dx.doi.org/10.1016/S0160-4120(02)00147-2

[2] Zhu, H., Yuan, X., Zeng, G., Jiang, M., Liang, J., Zhang, C., Yin, J., Huang, H., Liu, Z. and Jiang, H. (2012) Ecological Risk Assessment of Heavy Metals in Sediments of Xiawan Port Based on Modified Potential Ecological Risk Index. Transactions of Nonferrous Metals Society of China, 22, 1470-1477. http://dx.doi.org/10.1016/S1003-6326(11)61343-5

[3] Hu, W.F., Lo, W., Chua, H., Sin, S.N. and Yu, P.H.F. (2001) Nutrient Release and Sediment Oxygen Demand in a Eutrophic Land-Locked Embayment in Hong Kong. Environment International, 26, 369-375. http://dx.doi.org/10.1016/S0160-4120(01)00014-9

[4] Petticrew, E.L. and Arocena, J.M. (2001) Evaluation of Iron-Phosphate as a Source of Internal Lake Phosphorus Loading. Science of the Total Environment, 266, 87-93. http://dx.doi.org/10.1016/S0048-9697(00)00756-7

[5] Mihailova, P., Traykov, I., Tosheva, A. and Nachev, M. (2013) Changes in Biological and Physicochemical Parameters of River Water in a Small Hydropower Reservoir Cascade. Bulgarian Journal of Agricultural Science, 19, $286-289$.

[6] Yotinov, I., Lincheva, S., Kenderov, L., Schneider, I. and Topalova, Y. (2013) Evaluation of the Self-Purification in the Waters of the Micro-Dams in the Small Hydroelectric Power Plants (HEPPs) Lakatnik and Svrazhen: Potential of the Bioalgorithms. Bulgarian Journal of Agricultural Science, 19, 135-139.

[7] Todorova, Y. and Topalova, Y. (2013) Short-Time Effect of Heavy Metals Stress on Key Enzyme Indicators in River Sediments. Bulgarian Journal of Agricultural Science, 19, 282-285.

[8] Todorova, Y. and Topalova, Y. (2010) Modulation Effect of Heavy Metal Pollution on Key Enzyme Activities in River Sediments. Journal of Biotechnology, 150, 283-284. http://dx.doi.org/10.1016/j.jbiotec.2010.09.215

[9] Lincheva, S., Todorova, Y. and Topalova Y. (2014) Long-Term Assessment of the Self-Purification Potential of a Technologically Managed Ecosystem: The Middle Iskar Cascade. Biotechnology and Biotechnological Equipment, 28, 455-462. http://dx.doi.org/10.1080/13102818.2014.923623

[10] Vidali, M. (2001) Bioremediation. An Overview. Pure Applied Chemistry, 73, 1163-1172. http://dx.doi.org/10.1351/pac200173071163

[11] Tabak, H.H., Lens, P., van Hullebusch, E.D. and Dejonghe, W. (2005) Developments in Bioremediation of Soils and Sediments Polluted with Metals and Radionuclides-1. Microbial Processes and Mechanisms Affecting Bioremediation of Metal Contamination and Influencing Metal Toxicity and Transport. Reviews in Environmental Science and Bio/ Technology, 4, 115-156. http://dx.doi.org/10.1007/s11157-005-2169-4

[12] Perelo, L.W. (2010) Review: In Situ Bioremediation of Organic Pollutants in Aquatic Sediments. Journal of Hazardous Materials, 177, 81-89. http://dx.doi.org/10.1016/j.jhazmat.2009.12.090 
[13] Topalova, Y. (2009) Biological Control and Management of Wastewater Treatment. Publish ScieSet-Eco, Sofia.

[14] Arnosti, C. (2003) Microbial Extracellular Enzymes and Their Role in Dissolved Organic Matter Cycling. In: Sinsabaugh, R.L., Ed., Aquatic Ecosystems: Interactivity of Dissolved Organic Matter, Academic Press, San Diego, 315-342. http://dx.doi.org/10.1016/B978-012256371-3/50014-7

[15] Chrost, R.J. and Siuda, W. (2002) Ecology of Microbial Enzymes in Lake Ecosystems. In: Burns, R.C. and Dick, R.P., Eds., Microbial Enzymes in the Environment Activity, Ecology, and Applications, Marcel Dekker, Inc., New York, 3572. http://dx.doi.org/10.1201/9780203904039.ch2

[16] Chrost, R.J. (1992) Significance of Bacterial Ectoenzymes in Aquatic Environments. Hydrobiologia, 243-244, 61-70. http://dx.doi.org/10.1007/BF00007020

[17] Wlodarczyk, T. (2000) Some of Aspects of Dehydrogenase Activity in Soils. International Agrophysics, 14, $365-376$.

[18] Wilczek, S., Fischer, H. and Pusch, M. (2005) Regulation and Seasonal Dynamics of Extracellular Enzyme Activities in the Sediments of a Large Lowland River. Microbial Ecology, 50, 253-267. http://dx.doi.org/10.1007/s00248-004-0119-2

[19] Matavuly, M., Bokorov, M., Gayin, S., Gantar, M., Stoyilkovicy, S. and Flint, K.P. (1990) Phosphatase Activity of Water as a Monitoring Parameter. Water Science and Technology, 2, 63-68.

[20] Kenderov, L. and Yaneva, I. (2009) Ecological Characteristics of the Iskar River Catchment. Biotechnology and Biotechnological Equipment, 23, 276-280.

[21] APHA, AWWA and WEF (1989) Standard Methods for the Examination of Water and Wastewater. Washington DC.

[22] Lenhard, G., Nourse, L.D. and Schwartz, H.M. (1964) The Measurement of Dehydrogenase Activity of Activated Sludge. Advances in Water Pollution, 2, 105-107.

[23] Kochetov, G.A. (1980) A Practical Guide on Enzymology. High School, Moscow.

[24] EUR-Lex (2000) Directive 2000/60/EC of the European Parliament and of the Council Establishing a Framework for Community Action in the Field of Water Policy. http://eur-lex.europa.eu

[25] Alexander, M. (1994) Biodegradation and Bioremediation. Academic Press, San Diego.

[26] Lacerda, L.D., Fernandez, M.A., Calazans, C.F. and Tanizaki, K.F. (1992) Bioavailability of Heavy Metals in Sediments of Two Coastal Lagoons in Rio de Janeiro, Brazil. Hydrobiologia, 228, 65-70. http://dx.doi.org/10.1007/BF00006477

[27] Bryan, G.W. and Langston, W.J. (1992) Bioavailability, Accumulation and Effects of Heavy Metals in Sediments with Special Reference to United Kingdom Estuaries: A Review. Environmental Pollution, 76, 89-131. http://dx.doi.org/10.1016/0269-7491(92)90099-V

[28] US-EPA (2002) A Guidance Manual to Support the Assessment of Contaminated Sediments in Freshwater Ecosystems. Volume III-Interpretation of the Results of Sediment Quality Investigations. Washington DC.

[29] Lorenz, N., Hintemann, T., Kramarewa, T., Katayama, A., Yasuta, T., Marschner, P. and Kandeler, E. (2006) Response of Microbial Activity and Microbial Community Composition in Soils to Long-Term Arsenic and Cadmium Exposure. Soil Biology \& Biochemistry, 38, 1430-1437. http://dx.doi.org/10.1016/j.soilbio.2005.10.020

[30] Chaperon, S. and Sauve, S. (2007) Toxicity Interaction of Metals (Ag, Cu, Hg, Zn) to Urease and Dehydrogenase Activities in Soils. Soil Biology \& Biochemistry, 39, 2329-2338. http://dx.doi.org/10.1016/j.soilbio.2007.04.004

[31] Xie, W., Zhou, J., Wangb, H., Chen, X., Lu, Z., Yu, J. and Chen, X. (2009) Short-Term Effects of Copper, Cadmium and Cypermethrin on Dehydrogenase Activity and Microbial Functional Diversity in Soils after Long-Term Mineral or Organic Fertilization. Agriculture, Ecosystems and Environment, 129, 450-456. http://dx.doi.org/10.1016/j.agee.2008.10.021

[32] Cerón, L.E.R. and Ramírez, E.V. (2011) Microbial Activity in Soil and Sediments of the Upper Arzobispo River Basin. Agronomía Colombiana, 29, 257-263.

[33] Khan, S., Cao, Q., Hesham, A., Xia, Y. and He, J. (2007) Soil Enzymatic Activities and Microbial Community Structure with Different Application Rates of Cd and Pb. Journal of Environmental Sciences, 19, 834-840. http://dx.doi.org/10.1016/S1001-0742(07)60139-9 
Scientific Research Publishing (SCIRP) is one of the largest Open Access journal publishers. It is currently publishing more than 200 open access, online, peer-reviewed journals covering a wide range of academic disciplines. SCIRP serves the worldwide academic communities and contributes to the progress and application of science with its publication.

Other selected journals from SCIRP are listed as below. Submit your manuscript to us via either submit@scirp.org or Online Submission Portal.
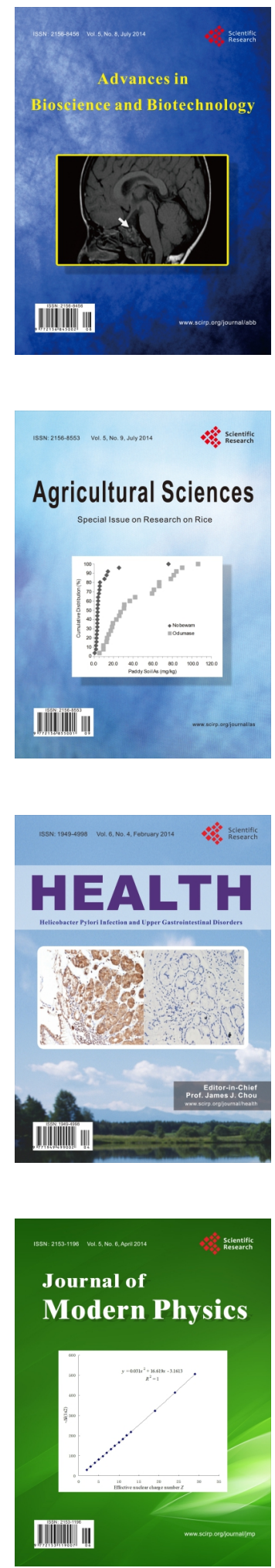
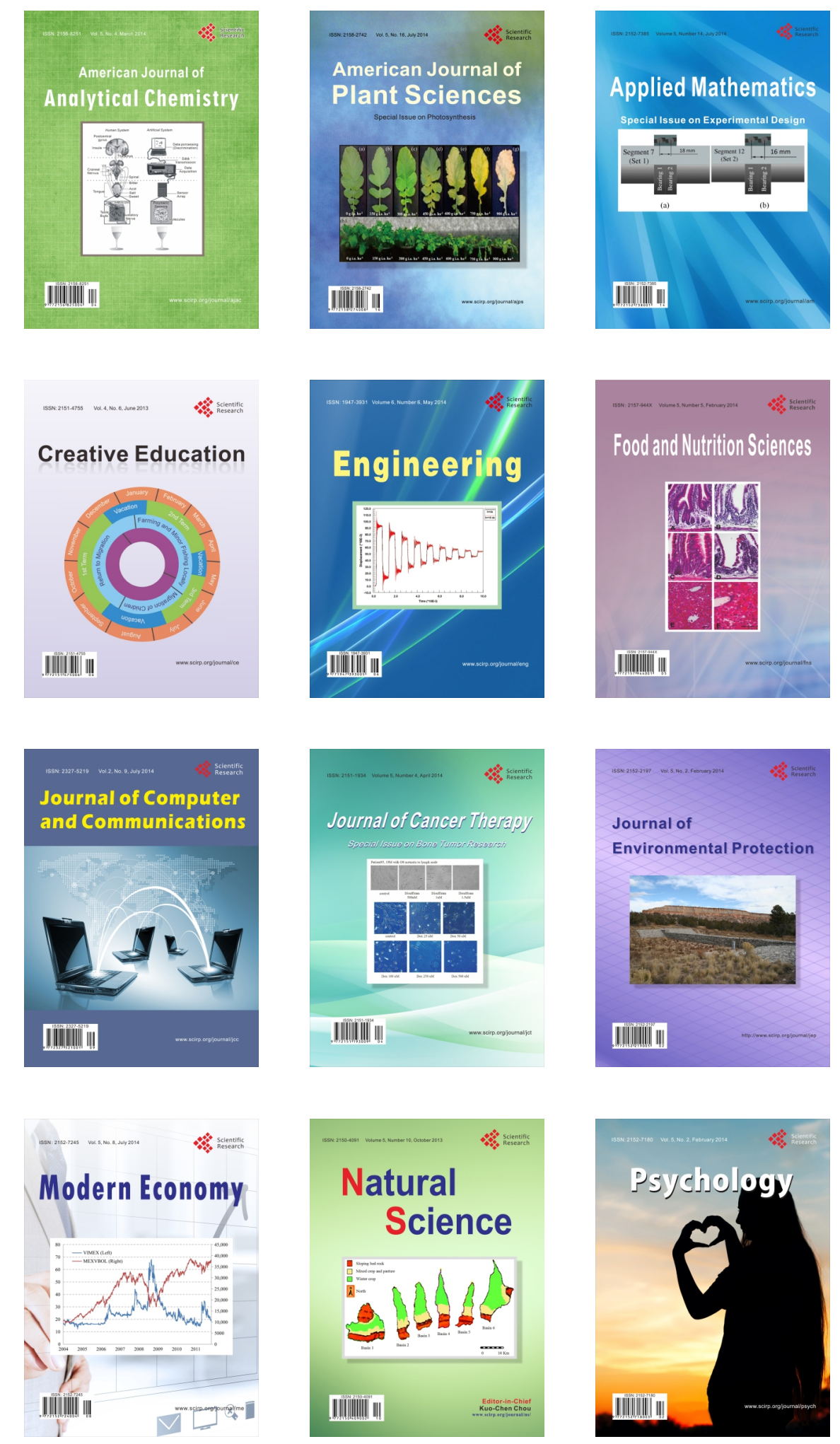